TIBOR ŽILKA

Univerzita Filozofa Konštantína v Nitre

\title{
SWÓJ I OBCY W PROZIE WĘGIERSKIEJ ORAZ SŁOWACKIEJ
}

Na wstępie rozważań należy wspomnieć, że wspólna historia narodów węgierskiego i słowackiego ciągnie się od czasów przybycia Węgrów do Kotliny Karpackiej, tj. od roku 896. Królestwo węgierskie mogłoby zapewne powstać bez przejęcia konkretnych administracyjno-organizacyjnych struktur Rzeszy Wielkomorawskiej, ale nie mogłoby w dłuższym czasie wzmacniać swojej potęgi. Nieprzypadkowo święty Stefan, założyciel państwa węgierskiego, przed wstąpieniem na tron w roku 1000, spędzał czas w Nitrze, znajdującej się w centrum Wielkiej Morawy, z pochodzącą z Ratyzbony (Regensburga), późniejszą jego żoną i królową Gizelą. Wspomnienie o królowej Gizeli zachowało się w nazwie nitrzańskiej katedry ${ }^{1}$ pod wezwaniem św. Emeráma. Święty ten również pochodził z Ratyzbony. ,Święty Emerám (Haimhram) przybył do Regensburga około 700 roku na zaproszenie wojewody Teodora"2. Po śmierci jego ciało pochowano w Kościele św. Jerzego w Regensburgu, gdzie pamięć o nim „w krótkim czasie przewyższyła pamięć o św. Erhardzie, starszym biskupie i patronie miasta"3. Żaden inny kościół w Europie Środkowej, poza Katedrą w Nitrze, nie nosi jego imienia. Nazwa nitrzańskiej katedry, tak jak nazwy innych kościołów, świadczy o zachodniej orientacji kultury słowackiej.

W efekcie opanowania przez plemiona węgierskie części terytoriów należących do Słowian zachodnich wielu pisarzy oraz wiele zabytków piśmienniczych i dzieł literackich, aż do okresu oświecenia i romantyzmu, uznaje się za wspólne dziedzictwo obu narodów. Zalicza się doń literaturę pisaną w języku łacińskim, np. legendę o św. Sworadzie i Benedykcie z XI wieku, a także dzieła niektórych autorów (Ján Sambucus, Matej Bel, Peter Benický itd.) z późniejszych czasów, należących zarówno do słowackiej, jak i węgierskiej tradycji literackiej ${ }^{4}$.

1 S. Sólymos, Szent Zoerard-András (Szórád) és Benedek remeték élete és kultusza Magyarországon, Budapest 1996, s. 18 .

2 R. Ondruš, Blizki Bohu i l'ud’om. Životopisy svätých, Bratislava 1991, s. 515.

3 Ibidem.

4 I. Käfer, Dona nobis pacem, Piliscsaba 1998, s. 60-62. 
Wyraźne zmiany noszące znamiona nabywania poczucia odrębności narodowej pojawiają się pod wpływem reformacji w późniejszych epokach, przede wszystkim po rozpoczęciu działalności przez Antona Bernoláka i jego zwolenników (bernolákovci), ale głównie po skodyfikowaniu słowackiego języka literackiego przez L’udovita Štúra w 1844 roku. Istniała już wówczas idea panslawizmu, będącego obroną przed szerzącymi się ideami pangermanizmu i panhungaryzmu. Terminu tego po raz pierwszy użył Ján Herkel w książce pt. Elementa Linguae Slavicae de Variis Dialectis Erupta et Sanis Logicae Principiis Suffalta (Buda 1926). Pewien paradoks polega w tym wypadku na tym, że Słowak Ján Kollár, od którego pochodzi idea wzajemności słowiańskiej, spędził z dala od ojczyzny najpierw dwa lata w Jenie, trzydzieści lat w Peszcie i ostatnie cztery w Wiedniu, przeżywszy w sumie lat pięćdziesiąt dziewięć. Nie szkodząc tożsamości słowackiej, idee panslawizmu oraz wzajemności słowiańskiej miały eliminować germańskie wpływy i przede wszystkim przeciwstawiać się węgierskiej ekspansywności. Tak ustosunkował się wobec tego problemu twórca słowackiego języka L'udovit Štúr: „Niehonorowe jest to jarzmo węgierskie dla Słowian i bardzo szkodliwe, niehonorowe, gdyż pochodzi od współrodaków mongolskich żyjących w naszych umysłach, w naszej sile, o czym świadczy cała historia Państwa Węgierskiego i najnowsza, szkodliwe, gdyż Węgrzy stoją na drodze wielkiemu zjednoczeniu się Słowian"s.

Nie ulega wątpliwości, że obie literatury rozwinęły się i nabrały swoistych, kontrastujących ze sobą cech pod wpływem idei narodowych rodem z XIX i początku XX stulecia. Sytuacja społeczna obu narodów nie była jednakowa. Aż do utworzenia Czechosłowacji w 1918 roku Węgrzy stanowili wyższą, a Słowacy niższą warstwę społeczną, co wpłynęło na ukształtowanie się różnych postaw oraz środowisk, w których te postawy funkcjonują. W węgierskiej literaturze, głównie prozie, Słowacy reprezentują typy ludowe, dominantą staje się w tym wypadku archetyp rolniczy, wymieniany w konkretnych przypadkach na archetyp pasterski ${ }^{6}$. Oczywiście, naszym zamiarem jest przedstawienie tylko niektórych dzieł $\mathrm{i}$ autorów, zatem będzie to analiza problemu w formie pars pro toto. Trudno tu mówić o jednoznacznej generalizacji. Jednakże mimo zróżnicowania postaw cechujących postaci Słowaków w prozie węgierskich autorów, można mówić o charakterystycznym środowisku, w jakim rozgrywają się konkretne wydarzenia. Oznacza to jednocześnie, że będziemy zwracać uwagę również na kod topograficzny i onomastyczny wspierający charakterystykę imagologiczną ${ }^{7}$.

W okresie romantyzmu w oparciu o antynomię swój - obcy symbolem słowackości w literaturze słowackiej stają się niebotyczne szczyty gór (Tatry, Szczyt Choczański, Krywań, Polana itd.), natomiast w literaturze węgierskiej funkcję tę przyjmuje nizina, wystarczy spojrzeć na fragment wiersza Sándora Petöfiego o jednoznacznym tytule Równina węgierska (Az alföld, 1844)

Pyszne Karpaty w koronie świerkowej!

Wasze uroki serca mi nie wzruszą,

W strome urwiska, w cieniste parowy

\footnotetext{
5 L. Štúr, Dielo. II, Bratislava 1986, s. 191.

${ }^{6}$ F. Miko, Estetika výrazu. Teória výrazu a štýlu, Bratislava 1969, s. 212-213.

${ }^{7}$ R. Barthes, S/Z, Budapest 1997, s. 32-34.
} 
Nigdy marzącą nie zbłąkam się duszą.

Milsza mi stepu przestrzeń niezmierzona

Step mi ojczyzną, nie oddam go za nic

Jak orzeł z gniazda, serce rwie się z łona,

Patrząc w widnokrąg - bez brzegu, bez granic.

(...)

(tłum. Seweryna Duchińska)

Wiersz ten zwraca uwagę na fakt, że w obu literaturach osobne rozważania należy poświęcić przestrzennej orientacji tekstu, którą nazwać można za Rolandem Barthes'em kodem topograficznym, powiązanym z systematyczną organizacją miejsc w narracji ${ }^{8}$. Należałoby zaznaczyć, że topograficzny kod jest równocześnie kodem kulturowym, o czym świadczy cytowany fragment utworu Petöfiego. Jak twierdzi Jurij Łotman: „model kultury ma swoją orientację wyrażającą się w określonej wartości, w stosunku między prawdą a fałszem, górą a dołem". Przy tym, najważniejszą cechą typologiczną przestrzeni jest u niego granica rozdzielająca tekst na dwie nieprzecinające się podprzestrzenie ${ }^{10}$. Może to być podział na swoich i obcych, w tym konkretnym przypadku sprowadzony do stosunku w przestrzeni zdominowanej przez społeczność węgierską, w której za obce uważane są realia słowackie. Obok kodu topograficznego osobne miejsce zajmuje kod onomastyczny, który w tym przypadku należy rozpatrywać z uwzględnieniem umiejscowienia postaci. Z punktu widzenia antynomii swój - obcy można przeanalizować występowanie postaci w obydwu literaturach na podstawie ich topograficznego przyporządkowania.

\section{Postaci węgierskie w prozie słowackiej w oparciu o antynomię swój - obcy}

Jak już wspomniano, nie ulega wątpliwości, że obie literatury rozwinęły się i nabrały swoistych, kontrastujących ze sobą cech pod wpływem idei narodowych z XIX stulecia. Kontrast jest najbardziej widoczny właśnie w prozie, w której można bezpośrednio przeanalizować obraz (typ, charakter) postaci Węgra w literaturze słowackiej i Słowaka w literaturze węgierskiej. Analiza problemu skupiać się będzie na niektórych dziełach i autorach od okresu realizmu poczynając, wtedy bowiem rozpoczyna się czas, w którym zauważamy konstytuowanie się typów, a tzw. bohaterowie pozostają w tle ${ }^{11}$. Oprócz zróżnicowania postaw należy uwzględniać również środowisko, w którym wydarzenie się rozgrywa. $\mathrm{W}$ prozie słowackiej postaci Węgrów występują zwykle jako ustalone typy bohaterów, które można bez większych przeszkód wyodrębniać i charakteryzować. Oto najbardziej reprezentatywne typy Węgrów w prozie słowackiej:

1. Węgier jako postać satyryczna występuje w dwóch odmianach: jako węgierski szlachcic (arystokrata lub postać przypominająca arystokratę) albo jako zdrajca (tzw. ma-

\footnotetext{
${ }^{8}$ P. Michalovič, P. Minár, Úvod do štrukturalizmu a postštrukturalizmu, Bratislava 1997, s. 113.

9 J.M. Łotman, Struktura tekstu artystycznego, thum. A. Tanalska, Warszawa 1984, s. 378-379.

${ }^{10}$ Ibidem, s. 237.

${ }^{11}$ D. Fokkema, E. Ibsch, Modernist Conjectures. A Mainstream in European Literature 1910-1990, London
} 1987, s. 36-37. 
dziaron, tzn. Słowak, który przyjął węgierską kulturę, narodowy, węgierski neofita - przyp. red.). Typowym przedstawicielem tej grupy jest Verešgál z Faustiády (1866) Jonáša Zaborskiego. Tak charakteryzuje go autor: „Jego ojciec nazywał się Verzgál, pochodził z Moraw (...) Syn natomiast zmienił się w Madziara, mówił po węgiersku ze wszystkimi naleciałościami tego języka, przejął pychę węgierskiego szlachcica i złość słowackiego renegata" 12 . Plejadę tych postaw rozszerzyła Zuzka Zguriška w powieści Metropolia pod słoma (Metropola pod slamou, 1949), gdzie małomiasteczkową elitę tworzą charakterystyczne postaci Węgrów, takie jak Kökényi, Nádassy itp. W tej satyrycznej powieści nobliwe społeczeństwo podlega całkowitemu ośmieszeniu. Również Peter Jaroš w swojej powieści Tysiacletnia pszczoła (Tisícročná včela, 1979) wyśmiewa zdradę Pála Szokolika. Jako „madziaron” dysponuje on cechami, które charakteryzują go w ramach społeczeństwa jako obcego.

2. Węgier jako postać negatywna, okrutna, przedstawiciel władzy. Postacią taką jest plutonowy Rona z powieści Milo Urbana Żywy bicz (Živý bič, 1963), pomimo braku jakiejkolwiek bezpośredniej wzmianki o tym, że jest Węgrem. Autor sygnalizuje jedynie jego przynależność narodową: „Ć́wiczenia ich oddziału prowadził niejaki plutonowy Rona, krępy chłop, gdzieś z południowego kraju. Miał małe czarne oczka, potężne wąsiska"13. Wąsy stały się cechą rozpoznawczą Węgra, wyrazem dzikości i sadystycznego okrucieństwa. (Przy okazji warto zaznaczyć, że typu okrutnego Węgra nadużywa się czasem we współczesnej walce politycznej, wystarczy porównać wypowiedzi przewodniczącego SNS (Slovenská Národná Strána - współczesna, narodowa partia polityczna, przyp. red.) o Wę$\operatorname{grach}^{14}$.

3. Węgier (Węgierka) jako typ postaci z temperamentem, posiadającej cechy erotyzujące środowisko, w którym przebywa. Chodzi głównie o postaci kobiece wzbudzające spory, jak Carmen ze słynnej opery Georges'a Bizeta. Postaci tego typu pojawiają się najważniejszych powieściach Ladislava Balleka: Pomocník (1977) i Agáty (1981). Mimo że w swoich utworach obrazuje on przede wszystkim południe kraju, postaci te nie należą bezpośrednio do społeczności węgierskiej. Temperament postaci kobiecych w jego prozie determinuje samo otoczenie. W okresie powojennym pełna temperamentu, powabna Węgierka pojawia się prozie Vincenta Šikuli. Chodzi o postać Andriki z autobiograficznej powieści Liesky (1980), którą charakteryzuje tak: „Również Andrika była Węgierką. Jednakże nie miała nic wspólnego z baletnicą Emike, o której pisał Rudolf Sloboda, mój współtowarzysz i przyjaciel"15.

4. Węgier jako typ przedsiębiorczego człowieka z miasta, stojącego w opozycji wobec typu słowackiego bohatera wiejskiego. Tę opozycję najwyraźniej reprezentują dwaj protagoniśći z powieści Balleka Pomocník Volent Lančarič i Štefan Riečan. Ballek z jednej strony podkreśla południowosłowiańskie pochodzenie Lančariča, z drugiej strony natomiast kreuje typową węgierską postać, która w swoich replikach nieustannie używa węgierskich słów. Zurbanizowanie wiąże się nie tylko z tzw. typami przedsiębiorców handlowych, ale również z miejską elitą, jej wyniosłością. Zurbanizowane typy postaci stanowią

\footnotetext{
12 J. Záborský, Faustiáda, Bratislava 1984, s. 55.

${ }_{13}$ M. Urban, Żywy bicz, thum. E. Witwicka, Warszawa 1966, s. 61.

${ }_{14}$ Andrej Danko (przyp. red.).

${ }^{15}$ V. Šikula, Liesky, Bratislava 1980, s. 20.
} 
często Węgrzy i Niemcy w przeciwieństwie wiejskich typów reprezentowanych przez słowackich chłopów.

5. Węgier jako przedstawiciel władzy, protagonista Słowaka reprezentującego zazwyczaj lud. Ten typ pojawia się w powieściach historycznych jako rzeczywista postać występująca w przeszłości, a wykreowana przez świadomość autora. Takim typem bohatera jest Peter Pázmány w powieści Ladislava Nádaši Jégégo Adam Šangala (1923) czy Tomáš Bakócz w powieści Jána Johanidesa Marek koniarz $i$ węgierski papież (Marek koniar a uhorský pápež, 1983), z podobnymi postaciami spotykamy się w powieściach historycznych Antona Hykischa Czas mistrzów (Čas majstrov, 1977) i Kochajcie królową (Milujte královnú, 1984). Postaci reprezentujące władzę nie są zazwyczaj sympatyczne, co wynika z wprowadzonej zasady postrzegania ich z plebejskiego punktu widzenia.

Należy zaznaczyć, że przedstawione typy przekształcają się czasem w stereotyp, po który chętnie sięgają twórcy ulegający chwilowym politycznym modom i ideologicznym falom. Wynika z tego, że w świadomości Słowaków - głównie tych, którzy ulegają mitycznym wyobrażeniom - przetrwały zakorzenione poprzez literaturę i sztukę wyobrażenia o żądnych władzy i apodyktycznych, dążących do zmiany granic, eo ipso nastawionych nacjonalistycznie Węgrach. Czasem cecha ta sięga granic okrucieństwa, sadyzmu (Rona w powieści M. Urbana $\dot{Z} y w y$ bicz). Z drugiej strony przypisuje się im temperament, ich znakiem rozpoznawczym stały się wąsy, ostra (piekąca) papryka, specyficzna cygańska muzyka i piosenki cygańskiego pochodzenia. Ich przestrzenią jest nizina, domeną konie, które wywołują asocjacje z przybyciem Węgrów na tereny zamieszkiwane niegdyś przez Słowian. Postaci węgierskie pojawiają się często w utworach literackich nawiązujących do środowiska miejskiego. Niekiedy podkreśla się ich przedsiębiorczość, wynalazczość, rzadziej kulturę czy chociażby wyższy poziom wykształcenia. Jednakże w tym wypadku poglądy nie są wyważone, istnieją również typy bohaterów będące znakiem zdegenerowania i upadku (przykładem mogą być postaci z powieści Zuzky Zgurišky). Niekiedy - mam na myśli okres komunizmu - węgierscy bohaterowie, kreowani pod wpływem odgórnych wytycznych, stają się wytworem ideologicznych schematów. Taką postacią jest komisarz Bende z powieści Vladimíra Mináča Żywi i martwi (Živí a mŕtvi, 1959), którego węgierskie pochodzenie nie jest tak ważne, jak jego rewolucyjna świadomość. Jest rewolucjonistą z powołania: „Urodził się z węgierskiej służącej z Berehova ponad pół wieku temu, cztery lata był na pierwszej wojnie światowej, a potem walczył w węgierskiej komunie i gnił w więzieniu białego terroru, poszedł za Karpaty, a potem była Hiszpania i międzynarodowe brygady, porażka i obozy koncentracyjne we Francji i długie lata konspiracji""16. Trudno mówić, nawiązując do komisarza Bendy, o typie bohatera, pełni on funkcję bojownika o tzw. dobro, czyli zwycięstwo postępowych (komunistycznych) idei. Mógłby być zarówno Niemcem, jak i Francuzem, poza pochodzeniem i replikami nasyconymi wyrażeniami obcymi (niesłowiańskimi), jako Węgier nie wyróżnia się niczym szczególnym.

Węgierskie postaci pojawiają się również w twórczości Petra Andruški, Andreja Chudoby, Ivana Habaja i przede wszystkim u Ladislava Balleka. To właśnie on opracowuje pod względem literackim nową koncepcję, sporządzając mapę środowiska południowo-słowackiego z wpisanymi weń bohaterami węgierskimi. Dzięki jego poetyce, opierającej się na teorii wpływu środowiska, które według określającej funkcji mileu Hippolita Tainego, de-

16 V. Mináč, Živí a mŕtvi, Bratislava 1978, s. 328. 
terminuje i predestynuje działanie ${ }^{17}$, postaci te podlegają silnej indywidualizacji. Na różnicę między poetyką Habaja i Balleka zwraca uwagę Robert B. Pynsent, pisząc: „Poglądy tych dwóch autorów dotyczące kwestii narodowościowej różnią się diametralnie. Postawa Habaja jest w swojej istocie romantyczna, a Balleka neoromantyczna. Romantyczna postawa ujmuje naród i narodowość jako produkt konfliktu (...) Ballek postrzega ludność bardziej jako komuny niż narodowość (...) Komuna Balleka z łatwością wchłania konflikt”"18.

Po roku 1989 zaczął się nowy okres w rozwoju literatury słowackiej. Cały system literacki uległ wówczas pluralizmowi, przejmując dominujące cechy z arsenału postmodernistycznych tendencji. Prawda, że trend parodystyczny oraz ironizowanie na temat zastanych schematów i stereotypów pojawiał się wcześniej, zmiany jedynie przyspieszyły ten proces, przemieszczając go z peryferii do centrum. Za przykład może posłużyć twórczość Lajosa Grendela, któremu nie poświęca się należytej uwagi ze względu na fakt, że jako autor literatury narodowej stanowi swoisty fenomen ${ }^{19}$. Postmodernizm, wprowadzając subwersję, podaje w wątpliwość typy, które z czasem przekształciły się w postaci zmityzowane i stereotypy. Aby stereotyp powstał i przetrwał, autorzy muszą zachować dwa podstawowe kryteria: odmienność postaci względem innych konstytuująca swoiste własności oraz ciągłość ustalonych własności podtrzymująca charakterystyczne cechy mimo zmieniających się okoliczności i upływu czasu. To właśnie te formy sztuka współczesna najczęściej parodiuje. Literatura staje się tym samym naśladowaniem, kopią innych tekstów. Trafną charakterystykę tego zjawiska znaleźć można u znanego czeskiego anglisty: „Jeśli modernizm jest kulturą oryginału, to postmodernizm jest kulturą kopii. Książki są kopiami innych książek. Ludzie są kopiami innych ludzi" ${ }^{20}$. Tak więc, podczas gdy jedna grupa autorów wysuwa na plan pierwszy zastane stereotypy Węgrów, ta druga w duchu kryteriów postmodernizmu stereotypy te parodiuje, burzy, podporządkowuje ich model swoistej subwersji ${ }^{21}$.

Za przykład może posłużyć tekst Pavla Vilikovskiego z książki Krutý strojvodca pod tytułem Pam para pam $^{22}$. Pretekstem dla powstania parodii Vilikovskiego była relacja radiowa z czasów totalitaryzmu, gatunek publicystyczny oparty na rozmowie. W tekście występują postaci: reporter (prowadzący dialog); rozmówca z hontańskiej wsi w czasie parady; Kecskeméthy, zastępca żupana hontiańskiej żupy z roku 1848; Rotarides, nauczyciel i współrebeliant romantycznego poety Janka Král'a; wójt z tego samego okresu; Misza, uczeń z dobrymi wynikami w szkole, który w czasach przymusowej madziaryzacji nauczył się języka węgierskiego dzięki nowym metodom (chodzi oczywiście o postać fikcyjną).

Autor przy parodyzacji stereotypu stosunków słowacko-węgierskich wykorzystał aż trzy płaszczyzny czasowe: pierwszą płaszczyznę stanowi okres socjalizmu z aplikowanym

${ }_{17}$ A. Vantuch, Š. Povchanič, K. Kenížová-Bednárová, S. Šimková, Dejiny francúzskej literatúry, Bratislava 1995, s. $135-136$.

${ }_{18}$ B.R. Pynsent, Národnosti južného Slovenska v Habajových a Ballekových dielach, „Romboid” 6 (1989), s. 77.

${ }^{19}$ Lajos Grendel należy do węgierskiej mniejszości na Słowacji. Był prezesem Stowarzyszenia Pisarzy Słowackich. Szczególną popularność przyniosła mu powieść o relacjach słowacko-węgierskich Nalunk, New Hontban (U nas w New Hont) z roku 2001 (przyp. red.).

${ }^{20}$ M. Hilský, Modernisté, Praha 1995, s. 243.

${ }^{21}$ P. Zajac, Štylistika, poetika, rétorika, w: Od moderny k postmoderne, edit. T. Žilka, Nitra 1997, s. 36.

${ }^{22}$ P. Vilikovský, Krutý strojvodca, Bratislava 1996, s. 106-118. 
weń fałszywym optymizmem, w czasach kiedy kolektywizację wsi traktowano jako sukces; druga płaszczyzna odnosi się do roku 1848 i postaci z tego okresu (zastępca żupana i wójt, oficjalni przedstawiciele władzy stający wobec rewolucjonisty Rotaridesa); trzecia płaszczyzna obejmuje współczesność; to, co kiedyś odnosiło się do słowackiej społeczności, dzisiaj ma przeciwstawną tendencję, można to ująć we frazie, iż w Europie Środkowej wszystko podlega powtórzeniu, ale w przeciwnym porządku. Oznacza to, że niegdysiejsi Węgrzy jako przedstawiciele władzy (zastępca żupana i wójt) przemawiają tak, jak niektórzy współcześni reprezentanci życia politycznego na Słowacji. Autor dokonuje tu bezsprzecznie rozrachunku z problemem władzy. Powstaje w wyniku tego swoisty typ logicznej schizmy, przewrotu, podkopania systemu literackiego, opierającego się na konstytuowaniu typu bądź indywidualności. Postaci nie są indywidualnościami, pełnią konkretną funkcję, nie są identyczne, ani homogeniczne, są jedynie nosicielami subwersji, która nie obala porządku czy systemu, ale go podkopuje, pozbawia oczywistej prawomocności, polemizując z nim, poddaje go w wątpliwość, wskazuje na jego paradoksalność, zróżnicowanie, dysjunktywność, nieprzejrzystość, omylność, zawiesza jego logikę ${ }^{23}$. Z tekstotwórczego punktu widzenia znamienne jest, że autor dopuszcza do mikrofonu nieżyjące osoby z XIX wieku (wójt, żupan, nauczyciel Rotarides), ale język, którym się porozumiewają odsyła do współczesności. Z punktu widzenia poetyki mamy do czynienia z prozopopeją oraz rodzajem anachronizmu, zakłócającego w tekście czas, wprowadzającego słowa, pojęcia, motywy, które w danym okresie nie mogły się pojawić. Przedstawione postaci z roku 1848 mówią do mikrofonu, a słuchają ich całe Węgry. Znamienne jest i to, że postaci wykorzystują wiele węgierskich słów, nawet całe zdania, opatrzone przypisem jak w stylu naukowym. Na końcu tekstu znajdują się przypisy - jest ich piętnaście - zawierające przekłady zdań z języka węgierskiego, ale nie na język słowacki, lecz angielski.

W ten sposób naruszony zostaje stereotyp Węgra w literaturze słowackiej, który zyskuje inne kontury. Dążył do tego również Rudolf Sloboda, pisząc o tym w swoich Pamätiach (1996), tego typu zabiegi literackie pojawiają także u Dušana Mitany. Twórcy dzieł nastawionych na rynek nadal jednak preferują typy powstałe pod wpływem zakorzenionych stereotypów i ideologicznych schematów, tak aby przeciętny odbiorca z łatwością dostroił się do przedstawianego tematu i absorbował dzieło literackie bez żadnego intelektualnego wysiłku.

\section{Postaci słowackie w prozie węgierskiej w oparciu o antynomię swój - obcy}

Pojawia się pytanie, jakie postaci słowackie występują w węgierskich dziełach literackich. Na początku należałoby powiedzieć, że słowiańskie nazwy, imiona oraz słowa wywołują u Węgra osobliwe asocjacje i bardzo często stają się źródłem humoru, co oczywiście pociąga za sobą odwrotny do zamierzonego skutek. Niewątpliwie, w kręgach węgierskich najbardziej narażony na parodiowanie jest język rosyjski i Rosjanie, ale nazwy i imiona słowiańskiego, zwłaszcza czeskiego pochodzenia występują w tekstach humorystycznych równie często. Najczęściej natomiast pojawia się w dziełach węgierskich autorów środowisko słowackie, występuje ono nawet u najwybitniejszych pisarzy (Mór Jókai,

${ }^{23}$ P. Zajac, op. cit., s. 36. 
Imre Madách, Kálmán Mikszáth) pochodzących z terenów dzisiejszej Słowacji, a także u Gyuli Krúdego. Mam tu na myśli nie tylko powieść Krúdego A podolini kisértet (Widmo $w$ dolinie, 1906), ale i inne dzieła, nawiązujące do tatarskiego miasteczka Podoliniec, w którym autor ukończył gimnazjum. Można się pokusić o typologię postaw Słowaków w węgierskich dziełach literackich:

1. Słowak jako postać reprezentująca czystość i nieskazitelność ludu, jako typ zwykłego człowieka trwającego mimo wpływu cywilizacji i miasta. Ten rodzaj bohatera pojawia się w dziełach K. Mikszátha Słowaccy rodacy (Tót atyafiak, 1881) i Dobrzy Połowcy (A jo pálocok, (1882). Chodzi w tym przypadku o takie postaci, jak przykładowo baca Tomáš Olej z opowiadania Ta czarna plama (Ez a fekete folt, 1881) albo kobziarz Lapaj z innego utworu. Akcja toczy się w górskim otoczeniu, co już samo determinuje życie postaci i jest znakiem słowackości, bo przecież Węgier jest przede wszystkim mieszkańcem niziny. Ten typ bohatera pojawia się również w powieści współczesnego węgierskiego pisarza Pála Závady, którego dzieło Poduszka Jagvigi (Jagviga párnája, 1997) przeanalizujemy na zakończenie rozważań. Jest to postać biedaka Gregora, którą jednoznacznie uznać można za pozytywną.

2. Słowak jako postać humorystyczna, ale nie satyryczna. Humorystyczny charakter może wypływać już z samych imion postaci, o czym świadczy powieść K. Mikszátha $P a-$ rasol świętego Piotra (Szent Péter esernyője, 1995), gdzie oprócz dwóch postaci, wszystkie mają słowackie imiona (Adamecz, Plachta, Krátki, Majzik, Sztolárik, Fajka, Kupeczky). Koresponduje to ze środkowo-słowackim krajobrazem, w którym rozgrywają się wydarzenia. Świadczą o tym nazwy miejsc, nabierających w tekście węgierskiego charakteru (Bjela Voda, Beszterce, Selmec). Nazwy wsi natomiast mają słowacki charakter, mimo że są wytworem wyobraźni autora (Glogova, Privorec, Uhlavňa).

3. Słowak jako postać tragiczna, wykluczona z powodu przynależności do mniejszości, zajmująca marginalną pozycję w społeczeństwie. Z taką postacią spotykamy się w powieści P. Závady Poduszka Jagvigi, jest nią ostatni członek wymierającego rodu, Miško Osztatní.

4. Słowak jako element zmanipulowanej grupy społecznej. Mam tu na myśli powieść K. Mikszátha Oblężenie Bystrzycy (Beszterce ostroma, 1894), na podstawie której powstała opera Jána Cikkera pod tym samym tytułem. Głównym bohaterem powieści jest właściciel zamku Nededza Štefan Pongrácz, który bawi się w wojnę, werbując z okolicy chłopów, dzieląc ich na dwie grupy i ubierając w żołnierskie uniformy $\mathrm{z}$ dawnej przeszłości. Jedna z grup zazwyczaj oblega zamek, podczas gdy druga go broni. Trwa to niekiedy wiele dni, całe tygodnie, a okolica śmieje się z tego. Autor wykorzystuje słowackie wyrażenia przy ogłoszeniu mobilizacji: hajducy Pongrácza z mieczem umoczonym w baraniej krwi chodzą od jednej chłopskiej chaty do drugiej i w języku słowackim nawołują ludzi do wojny:

„Wojna będzie ludzie!

Kiedy się już zbiorą, rozdzielą ich na dwie grupy z okrzykiem:

$\mathrm{Na}$ dwie strony chłopcy"24.

${ }^{24}$ K. Mikszáth, Beszterce ostroma. Új Zrínyiász, Budapest 1960, s. 14-15. 
Mikszáth czerpał pomysły ze słowackiego krajobrazu, a jego dzieła są wypełnione postaciami słowackiego pochodzenia. Odkrywając piękno przyrody słowackiej, umiejscawia tam wydarzenia swoich opowiadań i niektórych powieści. W jego dziełach często występują nazwy słowackich miast (Žilina, Banská Štiavnica, Banská Bystrica, Modrý Kameň itd.), ale oprócz środowiska, to właśnie słowaccy bohaterowie główni nadają jego dziełom oryginalny charakter. W opowiadaniach Słowaccy rodacy (Tót atyafiak, 1881) i Dobrzy Połowcy (1882) większość bohaterów jest słowackiego pochodzenia, o czym świadczy nie tylko otoczenie, ale również imiona postaci (Olej, Filcsik, Mirkovszki, Makovnik itp.).

Do tradycji wytworzonej przez K. Mikszátha nawiązuje powieść P. Závady Poduszka Jagvigi. Powieść ogłoszono w 1997 roku, a jej autor otrzymał za nią prestiżową nagrodę im. Józefa Attili. Obecnie w przygotowaniu jest jej niemieckie wydanie, słowackie już się ukazało. Autor napisał też radiową adaptację powieści, istnieje również jej wersja filmowa. Jest to powieść, która podważa kryteria powieści klasycznej i postklasycznej, wykorzystując postmodernistyczną strategię narracji. Wydarzenia rozgrywają się przede wszystkim w środowisku słowackim, odnosząc się równocześnie do związków niemieckich i austriackich. Wydarzenia koncentrują się głównie na okolicy Tótkomlóša i częściowo Békešskej Čaby, chociaż nazwa Komlóša bezpośrednio w powieści nie występuje, według opisu można jednoznacznie zidentyfikować miejsce wydarzeń.

Należałoby dla ścisłości powiedzieć, że obydwa miasta znajdują się w południowej części Węgier i stanowią centrum słowackiej mniejszości. Słowacy przywędrowali tam w czasach panowania Marii Teresy (1740-1780), kiedy po tureckiej ekspansji zaludniano południowe regiony, przesiedlając mieszkańców z terenów dzisiejszej Słowacji. Potomkowie przesiedleńców długo podtrzymywali swoją słowacką narodowość, zachowując ją częściowo do dzisiaj. W jakich okolicznościach się to odbywało, można dowiedzieć się właśnie z powieści P. Závady.

Autor w literacki sposób ukazuje, jak Słowak reprezentujący mniejszość nieustannie zajmuje marginalną pozycję społeczną. Na końcu powieści wymiera cała rodzina, która jeszcze na początku stulecia należała do europejskiego kontekstu społeczno-kulturowego. Zaistniała sytuacja jest nie tylko rezultatem stosunków słowacko-węgierskich, ale skutkiem wyraźnych zmian zachodzących w Europie w XX stuleciu. I do takiego wniosku prowadzić mogą powyższe rozważania dotyczące wartościowania i analizy słowackich bohaterów w prozatorskich dziełach węgierskich pisarzy. Na zakończenie trzeba powiedzieć o jeszcze jednym znaczeniu dzieła Závady: „W ostatnim czasie współczesna węgierska literatura stała się jedynie smakołykiem elity, nieczytelnym balastem dla tych, którzy nie zostali wybrani, a wtedy pojawiła się powieść, która zaszokowała zarówno miłośników językowych eksperymentów literatury postmodernistycznej, jak i sceptyków, którzy już nie wierzyli, że współczesna literatura może ich jeszcze zainteresować" 25 . Z podobną sytuacją mamy do czynienia we współczesnej literaturze amerykańskiej, w której Don DeLillo, Bred Easton Ellis, Susan Sontag, Toni Morrison, Richard Ford i inni przejawiają ogromne zainteresowanie odbiorcą, konstytuując swoje teksty tak, aby zapewnić sobie „doskonały odbiór", co kłóci się z dotychczasowymi praktykami postmodernizmuª a ałównie jego

${ }^{25}$ R. Deáková, V trojitom zrkadlení, „Revue svetovej literatúry”, 3 (1998), s. 5.

${ }^{26}$ N. Vietorová, Postmodernizmus $v$ anglickej a americkej literatúre, w: Kapitoly z moderny, avantgardy a postmoderny, III, edit. I. Cvrkal, Bratislava 1996, s. 200-201. 
pierwszej fali do roku 1980. Jednym z preferowanych tematów współczesnej literatury staje się właśnie multikulturowość.

Podsumowując można postawić tezę, że słowacko-węgierskie kontakty są przydatnym tematem badań przestrzennej orientacji tekstu na bazie antynomii swój - obcy. Świadczą o tym nie tylko dzieła K. Mikszátha z końca ubiegłego i początku obecnego stulecia, ale również teksty literackie L. Balleka z lat siedemdziesiątych i osiemdziesiątych, najwyraźniejszy dowód stanowi powodzenie powieści Pála Závady Poduszka Jadvigi. W ramach przestrzennej orientacji tekstu węgierskie postaci w słowackich powieściach są, krótko mówiąc, cudzymi elementami, ale po części jest również odwrotnie. Jednakże tylko wtedy, kiedy węgierska proza nie domaga się wchłonięcia słowackich przestrzeni w swój świat. W takich wypadkach również bohater słowacki w węgierskiej prozie wchodzi w skład rodzimej przestrzeni (węgierskiej). Przykładem tego są utwory starszej literatury.

\section{Bibliografia}

Barthes R., S/Z, Budapest 1997.

Deáková R., V trojitom zrkadlení, „Revue svetovej literatúry”, 3 (1998).

Fokkema D., Ibsch E., Modernist Conjectures. A Mainstream in European Literature 1910-1990, London 1987.

Hilský M., Modernisté, Praha 1995.

Käfer I., Dona nobis pacem, Piliscsaba 1998.

Łotman J.M., Štruktúra umeleckého textu, prel. M. Hamada, Bratislava 1990.

Łotman J.M., Struktura tekstu artystycznego, thum. A. Tanalska, Warszawa 1984.

Michalovič P., Minár P., Úvod do štrukturalizmu a postštrukturalizmu, Bratislava 1997.

Miko F., Estetika výrazu. Teória výrazu a štýlu, Bratislava 1969.

Mikszáth K., Beszterce ostroma. Új Zrínyiász, Budapest 1960.

Mikszáth K., Tót atyafiak. A jó palócok. Beszterce ostroma, Budapest 1986.

Mikszáth K., Parasol świętego Piotra, tłum. C. Mondral, Warszawa 1997.

Mináč V., Živí a mŕtvi, Bratislava 1978.

Ondruš R., Blizki Bohu i l'ud'om. Životopisy svätých, Bratislava 1991.

Pynsent B.R., Národnosti južného Slovenska v Habajových a Ballekových dielach. „Romboid” 6 (1989), s. 77-81.

Sólymos S., Szent Zoerard-András (Szórád) és Benedek remeték élete és kultusza Magyarországon, Budapest 1996.

Šikula V., Liesky, Bratislava 1980.

Štúr L., Dielo. II, Bratislava 1986.

Urban M., Živý bič, Bratislava 1979.

Urban M., Żywy bicz, tłum. E. Witwicka, Warszawa 1966.

Vantuch A., Povchanič Š., Kenížová-Bednárová K., Šimková S., Dejiny francúzskej literatúry, Bratislava 1995.

Vietorová N., Postmodernizmus v anglickej a americkej literatúre, w: Kapitoly z moderny, avantgardy a postmoderny, III, edit. I. Cvrkal, Bratislava 1996, s. 196-209.

Vilikovský P., Krutý strojvodca, Bratislava 1996.

Záborský J., Faustiáda, Bratislava 1984.

Zajac P., Štylistika, poetika, rétorika, w: Od moderny k postmoderne, edit. T. Žilka, Nitra 1997, s. 29-41. 
TIBOR ŽILKA

\section{The self and non-self in Slovak and Hungarian prose}

\section{Summary}

In the 19th century, Hungarian and Slovak literature markedly specified and acquired contrasting features. The author states that in the Hungarian literature, especially in prose, Slovaks tend to represent folk types with the prevailing peasant archetype. Hungarians formed the upper class of the society until the establishment of Czechoslovakia in 1918 which also impacted the choice of literary protagonists and environments. The author of this study examines the image of Hungarians in Slovak prose the image of Slovaks in Hungarian prose. Consequently, he has created a typology of characters and environments in an attempt to apply imagology when comparing literary works of Hungarian and Slovak origin.

Keywords: Hungarian prose, Slovak prose, literary character, environment, poetics, imagology. 